\title{
Digital Geological Model (DGM): a 3D raster model of the subsurface of the Netherlands
}

\section{J.L. Gunnink ${ }^{*}$, D. Maljers, S.F. van Gessel, A. Menkovic \& H.J. Hummelman}

TN0 - Geological Survey of the Netherlands, P.0. Box 80015, 3508 TA, Utrecht, the Netherlands

* Corresponding author. Email: jan.gunnink@tno.nl

Manuscript received: January 2012, accepted: February 2013

\section{Abstract}

A 3D geological raster model has been constructed of the onshore of the Netherlands. The model displays geological units for the upper 500 $\mathrm{m}$ in 3D in an internally consistent way. The units are based on the lithostratigraphical classification of the Netherlands. This classification is used to interpret a selection of boreholes from the national subsurface database. Additional geological information regarding faults, the areal extent of each unit and conceptual genetic models have been combined in an automated workflow to interpolate the basal surfaces of each unit on $100 \times 100$ metre ( $x, y$ dimensions) raster cells. The combination of all interpolated basal surfaces results in a 3D Digital Geological Model (DGM) of the subsurface. A measure of uncertainty of each of these surfaces is also given. The automated workflow ensures an easily updatable subsurface model. The outputs are available for end users through www.dinoloket.nl.

Keywords: 3D geological modelling, Digital Geological Model (DGM), subsurface of the Netherlands

\section{Introduction}

The shallow Dutch subsurface (up to $500 \mathrm{~m}$ depth) has been mapped for many decades: the first geological map was at a scale of $1: 200,000$ (Staring, 1856; 1860), followed by a geological map at a scale of $1: 50,000$, which was surveyed and compiled between 1918 and 1942 (Tesch, 1942a; 1942b), and the new geological map at a scale of $1: 50,000$ which was carried out between 1953 and 2000 (RGD, 1953-1997; NITG-TN0, 1997-2000). The results of this most recent mapping program were published as paper maps and include smaller scale subsidiary maps, cross-sections and an explanatory booklet for each individual map sheet. A nation-wide summary was published at a scale of $1: 600,000$ (Zagwijn \& Van Staalduinen, 1975). Although these products display a wealth of geological information, they are merely an analogue $2 \mathrm{D}$ representation of the complex $3 \mathrm{D}$ configuration of the geological sequences in the subsurface.

Today, intensive usage of the subsurface and the interaction with activities above the surface are creating ever growing demands for detailed 3D subsurface information (Berg et al., 2011). The need for an internally consistent nation-wide framework model, representing the geological sequence in the upper hundreds of metres of the subsurface, is therefore increasingly required. To meet this need, a new way of calculating and presenting the subsurface has been developed.

The 3D geological framework model Digital Geological Model (DGM) displays the architecture of the Dutch subsurface. Basically, it consists of stacked lithostratigraphical units, providing 3D subsurface information mainly at the geological formation level. The model is constructed for the onshore part of the Netherlands and its units are based on the lithostratigraphy for Neogene and Quaternary deposits in the Netherlands (Westerhoff et al., 2003; Ebbing et al., 2003; Weerts et al., 2004).

The current DGM ( $\mathrm{v} 1.3$ ) consist of 31 geological units: 25 Formations, 3 Members and 3 combined units. The units represent the main depositional environments: marine, fluvial, glacial and a supplementary depositional domain that contains deposits of mixed and often local origin. One of the combined units is formed by the wedge of Holocene deposits in the fluvial and coastal plain. For the purposes of DGM, these Holocene deposits are amalgamated into the 'Holocene' unit. This unit consists of sedimentary sequences of intercalated fluvial, marine, tidal and 
organic deposits that cannot be modelled properly at a nationwide scale. The Peize and Waalre Formations (deposits from the Eridanos and the Rhine rivers respectively) are combined into one unit because of the complex interfingering of both formations in the central part of the Netherlands. Repeated interfingering is hard to model satisfactorily using the techniques described in this paper. The third combined unit comprises the ice-pushed sediments formed during the Saalian glaciation.
An overview of the geological units modelled in DGM is listed in Table 1. The maximum depth of DGM (which is not reached in the entire country) is about $1200 \mathrm{~m}$ below NAP (Dutch Ordnance Datum), which is the depth of the base of the Miocene Breda Formation in the Roer Valley Graben. Some units were not modelled across the entire country, as indicated in Table 1, and are only located in the southernmost part (Limburg), southwest (Zeeland) or eastern part of the country (Twente).

Table 1. List of the modelled units in Digital Geological Model (DGM, version 1.3) with depositional domain, main composition and age.

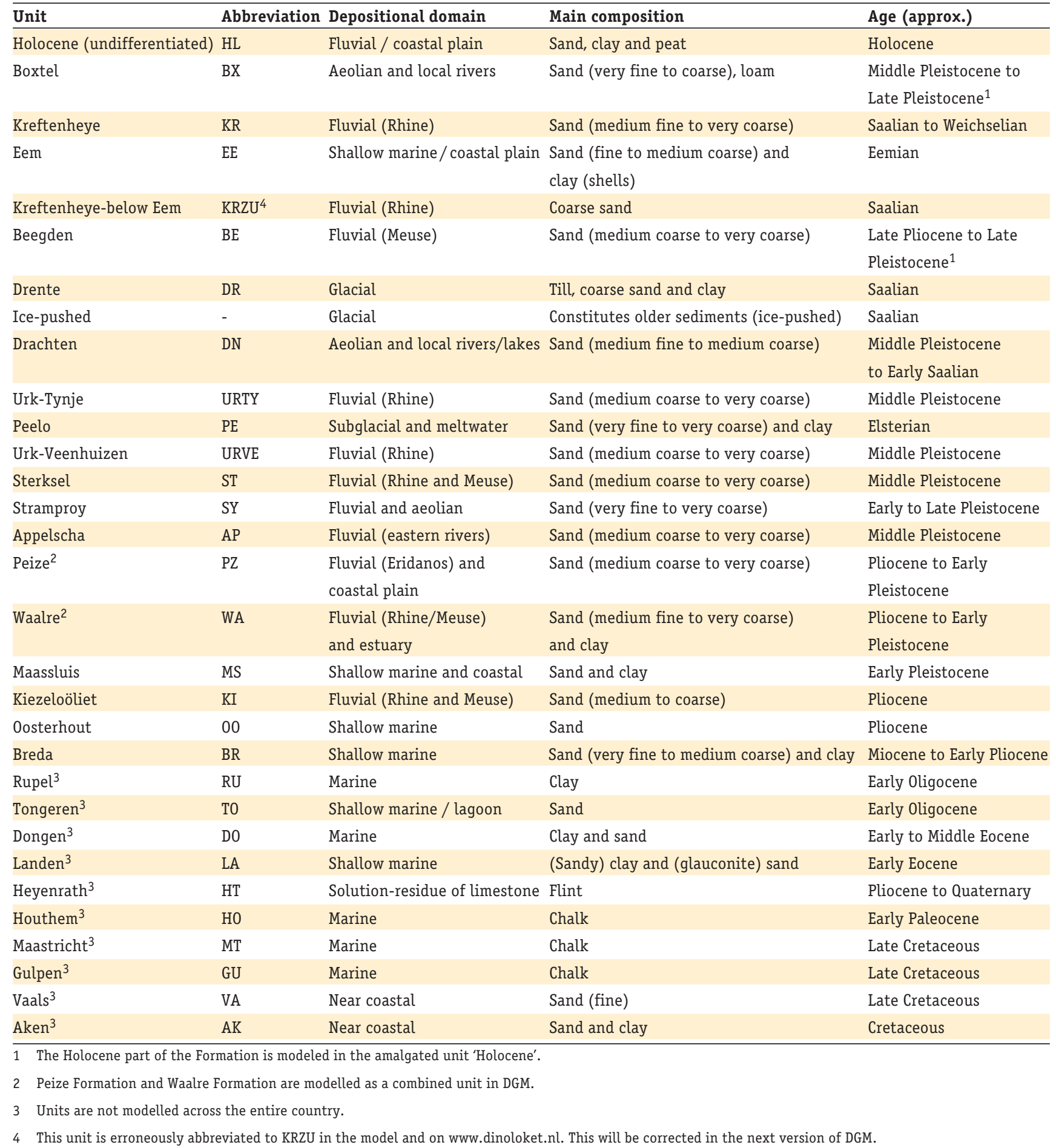


The longer term objective of the Geological Survey of the Netherlands is to supply users with consistent subsurface information for assessing the resources and geohazard potential in the Netherlands. The goal for the construction of DGM was to provide a nationwide framework to support further interpretation and modelling of the subsurface for applied use.

DGM is constructed with modern modelling techniques and is distributed through WWW technology, while in the meantime aims to maintain consistency with earlier information and mapping products. In this way, DGM stands on the shoulders of its predecessors, the paper maps, cross-sections and the underlying geological concepts.

DGM is a 3D model that shows a generalisation of the subsurface in terms of geological units. Modelling the subsurface inevitably requires a range of decisions: selection of boreholes, interpretation of the genesis, continuity and superposition of units, lithostratigraphical classification and interpolation parameters, to mention just a few. These decisions are interpretations (models) of the data that in the end result in a 3D representation of the subsurface. In this way, the interpreted data and DGM itself are both models. Model and modelling is used in this paper along this line of thinking: selection and interpretation of data and - spatial - results (faults, areal extent of units, basal surfaces) are all abstractions of the reality we try to capture.

\section{Data}

\section{Introduction}

DGM has been constructed using boreholes as the primary data source, combined with faults, areal extent of the geological units and supplementary data (trend surfaces, so-called steering points for modelling pinching out, etc.). These data are combined in an automated workflow that is used for preprocessing, creation of surfaces and post-processing (Fig. 1). The workflow ensures that the model is easy to update, to improve and to reproduce. Unlike the traditional map, DGM incorporates quantitative estimates of uncertainties.

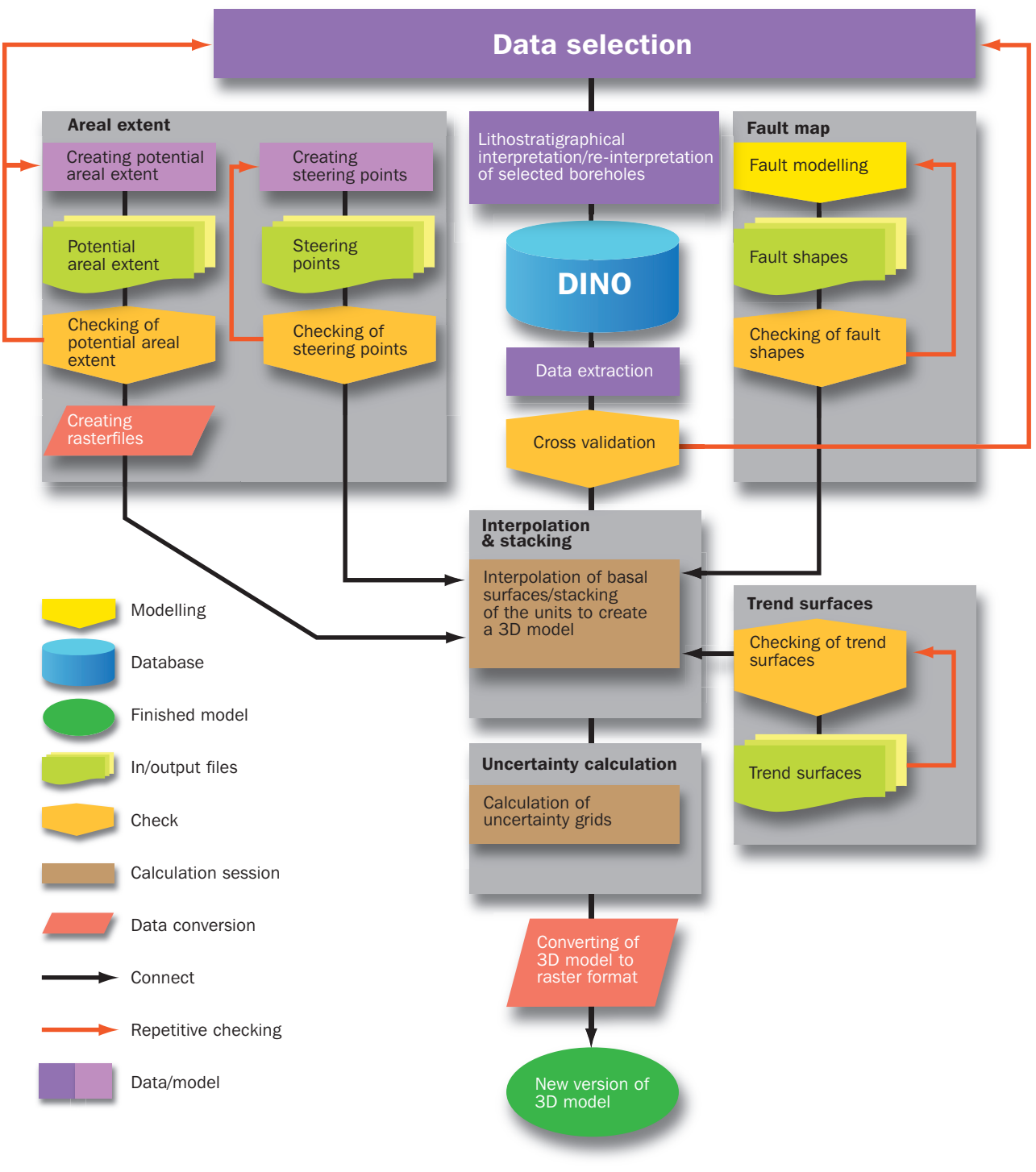




\section{Borehole data}

Approximately 16,500 onshore boreholes were used for the creation of DGM. These were selected from a larger collection of about 425,000 (onshore) boreholes that are stored in DIN0 (Data en Informatie van de Nederlandse 0ndergrond). This is a relational database containing subsurface data, which is developed and maintained by TNO - Geological Survey of the Netherlands (www.dinoloket.nl). The selection of boreholes (Fig. 2) is aimed at an even distribution of high quality borehole data with sufficient penetration depth into the Quaternary and Neogene to Cretaceous deposits. The quality of the borehole data was mainly judged by the details in the description of the lithological intervals. Boreholes with only a description of main lithology (without admixtures) were omitted. On the other hand, in specific cases boreholes with only a coarse description of the lithological content, but penetrating deep into the sedimentary sequence, were added to the borehole dataset to characterise the deeper units.
The selected boreholes were interpreted according to the lithostratigraphical classification of Ebbing et al. (2003), resulting in a data set which comprises point information on the top and base of each lithostratigraphical unit. Nationwide cross-sections and complementary regional cross-sections were compiled to aid the consistent interpretation of the boreholes into lithostratigraphical units. The resulting set of borehole data formed the base of the modelling procedure. Additional information to support the lithostratigraphical interpretation was retrieved from geophysical well-log data (i.e. gamma-ray) and seismic surveys.

\section{Fault map}

The fault map (Fig. 3) displays faults and fault blocks (assuming only vertical movement along the faults) and was used to determine the effect of fault movement on both the thickness and areal extent of each of the lithostratigraphical units. The position of the faults in relation to the base of every unit was

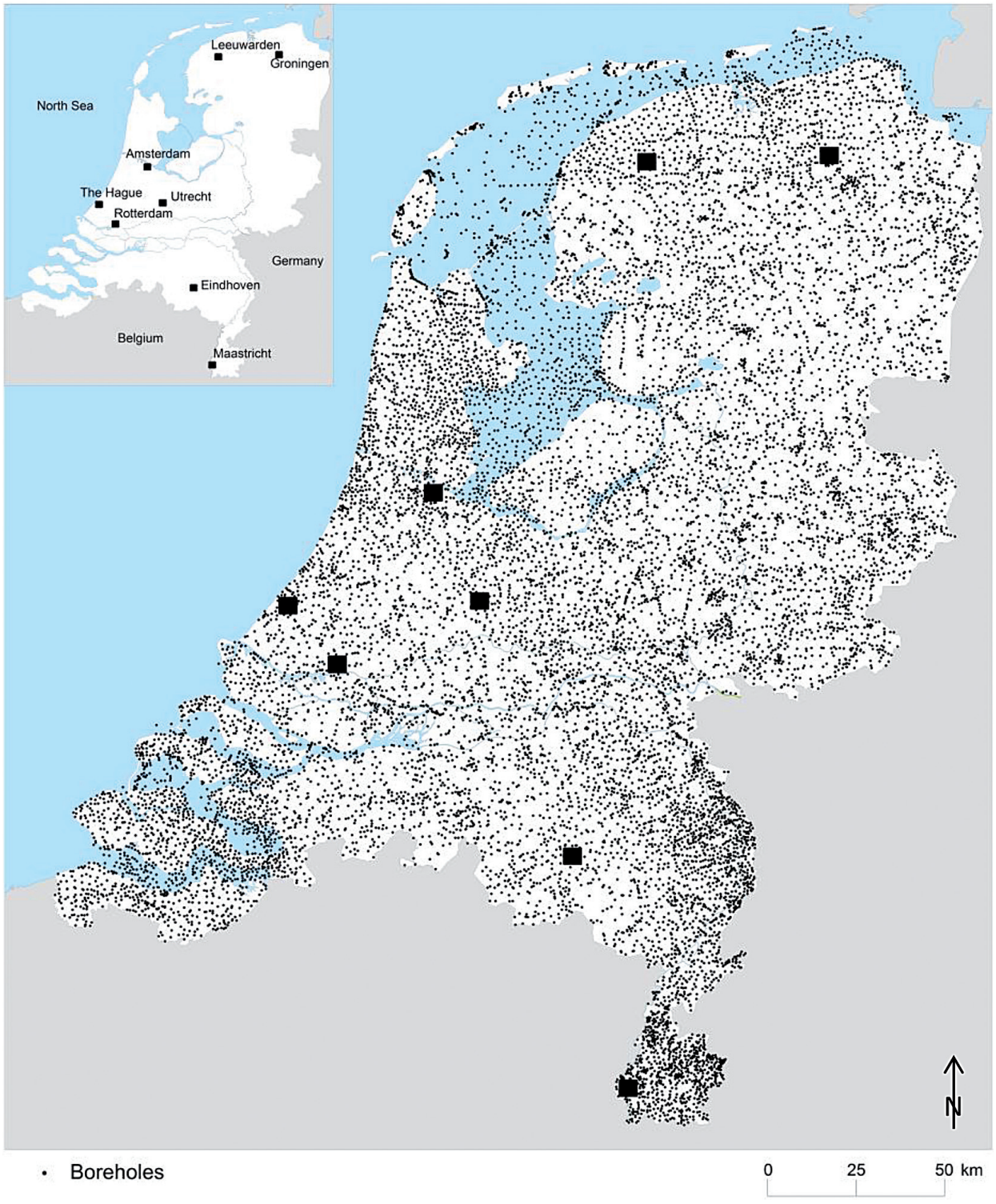

Fig. 2. Location of boreholes used in the modelling of DGM. Note the even distribution across the country, except for the southeasternmost part (Limburg). Here, more boreholes are needed to model the effect of faulting and tilting of fault blocks. 
determined. Besides the information from boreholes, seismic data (both shallow - <100 m depth - and deep) were used to determine the direction of tilting for each individual fault block, as well as the relative movement of the fault blocks. Regional cross-sections were constructed to provide insight in the fault movement associated patterns of erosion and deposition. For example, fault movement and subsidence in the tectonically active area of the southern Netherlands have resulted in major regional to local differences in distribution and thickness of several Neogene and Quaternary formations, Fig. 4 (adapted from Westerhoff, 2009). As a result, the fault map carries information whether faults have been active or not (synsedimentary as well as postsedimentary) for each unit and where fault activity extends up to the present-day surface.

The currently used tectonic map is a compilation of all known major onshore faults in the, Paleogene, Neogene and Quaternary deposits of the Netherlands. This is a thorough revision of the fault patterns published in past mapping programmes by the Geological Survey of the Netherlands and its predecessors and compiled in NITG-TNO (2004). High-resolution seismic data obtained along the Meuse river and adjacent canals were used to improve the fault mapping for the upper ca $500 \mathrm{~m}$ in the Roer Valley Graben, Peel Block and Venlo Block. For other parts of the Netherlands the fault map has been improved by analysing detailed borehole cross-sections and in some cases by field evidence.

\section{Areal extent}

The potential areal extent of every unit, defined as the area in which the unit was potentially deposited (Fig. 5) was determined from the lithostratigraphically interpreted borehole data, information resulting from former mapping programmes and expert knowledge of the geological history. However, as a result of erosion the present-day areal extent of a formation often shows a smaller area.

The areal extent primarily serves as the geographical limit within which the modelling of the basal surfaces was carried

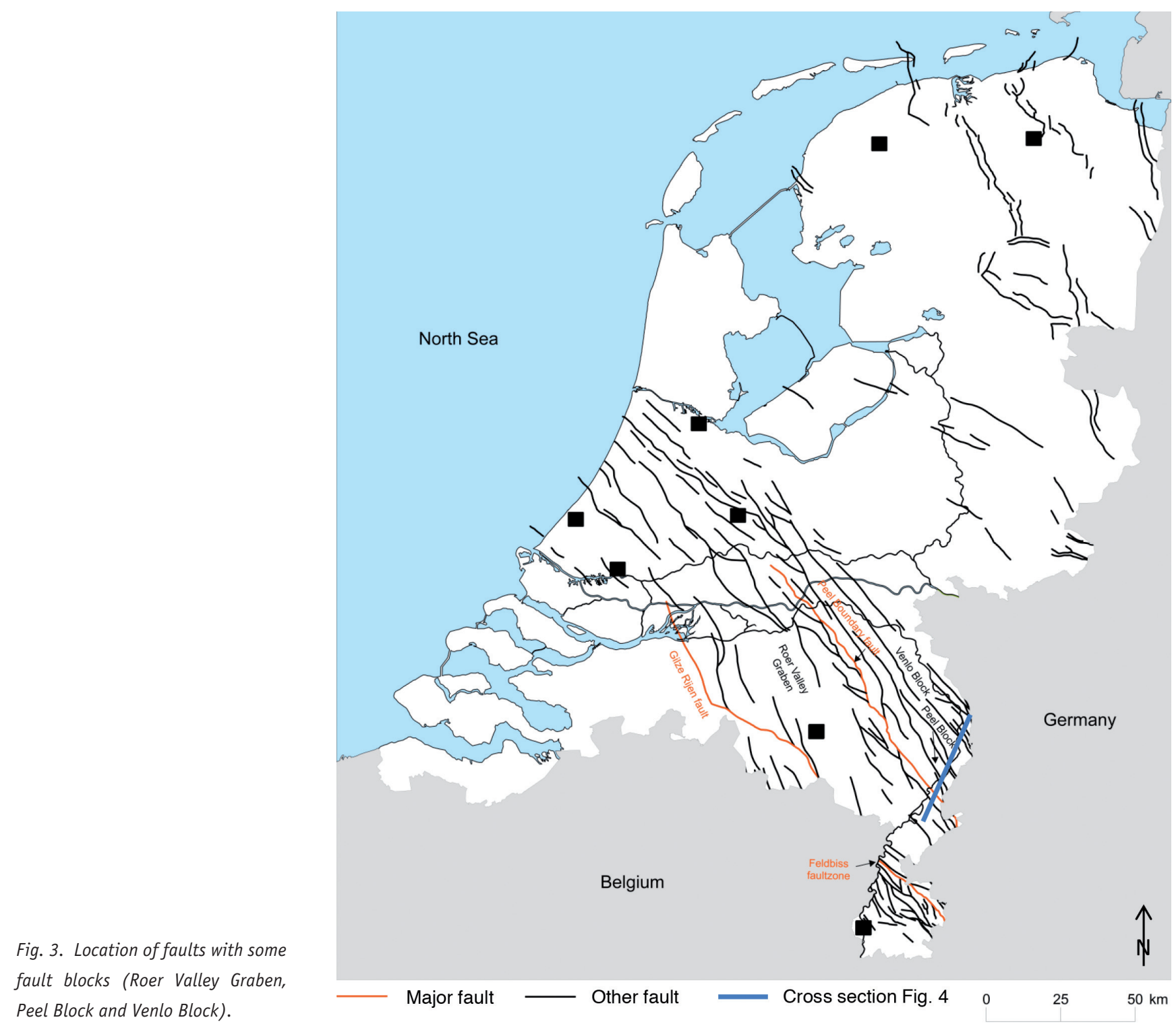




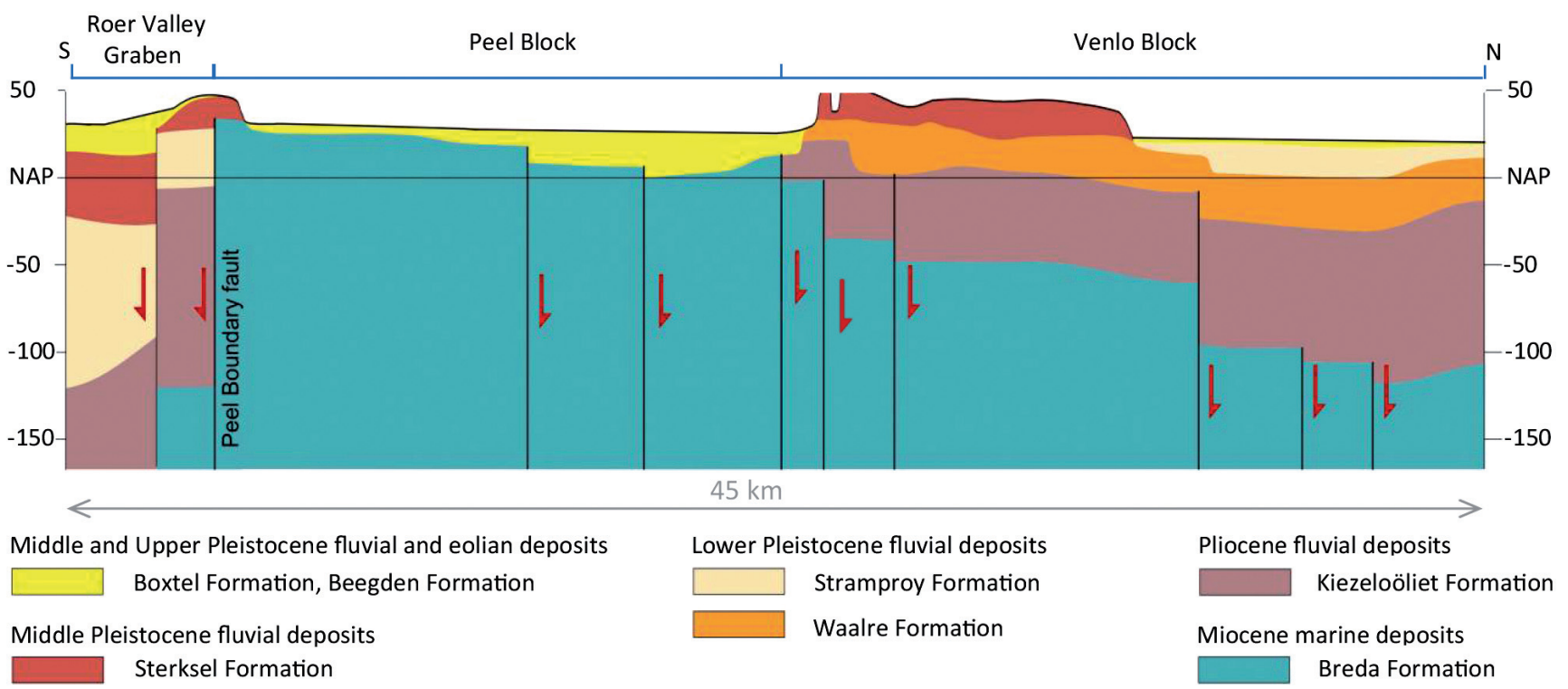

Fig. 4. Cross-section through the Roer-Valley Graben (for location see Fig. 3) to illustrate the effect of faulting on sediment deposition. The Peel Block shows older sediments (Breda Formation) close to the surface, while in the Roer Valley Graben thick sediments from younger formations occur (Sterksel and Stramproy Formations). This also applies to the Venlo Block.

out. Outliers in the dataset were judged on their relevance and this sometimes led to adjustments in the originally defined extents. In cases where units terminated abruptly (e.g. near faults or erosional boundaries) or where a unit thinned out, additional so-called steering-points were added in order to help the interpolation to create plausible geological units and relationships (Fig. 6).

\section{Trend surfaces}

Standard interpolation of borehole data alone often fails to produce a reliable representation of geological surfaces. Interpolation techniques assume a smooth undulating surface, while geological surfaces might instead show a range of forms, e.g. V-shapes, formed by incision, bowl-shaped forms such as basin fills and dipping strata. In order to obtain geologically plausible results we have used trend surfaces to steer the interpolation process. The trend surfaces were based on prior knowledge of the geological units resulting from e.g. previous mapping programmes and focus at the shape, depth and the geological processes that controlled the development of the units.

In Fig. 7 two examples are presented of geological features for which a trend surface is considered indispensable: Figure $7 \mathrm{a}$ shows buried valleys (tunnel valleys) resulting from deep glacial incisions during the Elsterian ice-age and in Fig. 7b a surface, showing the general northwest-dipping trend of the base of the shallow marine 0osterhout Formation is displayed.

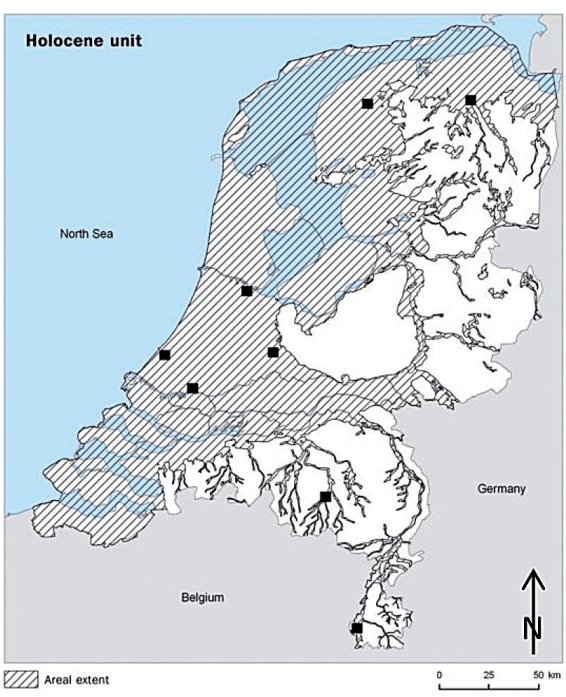

a.

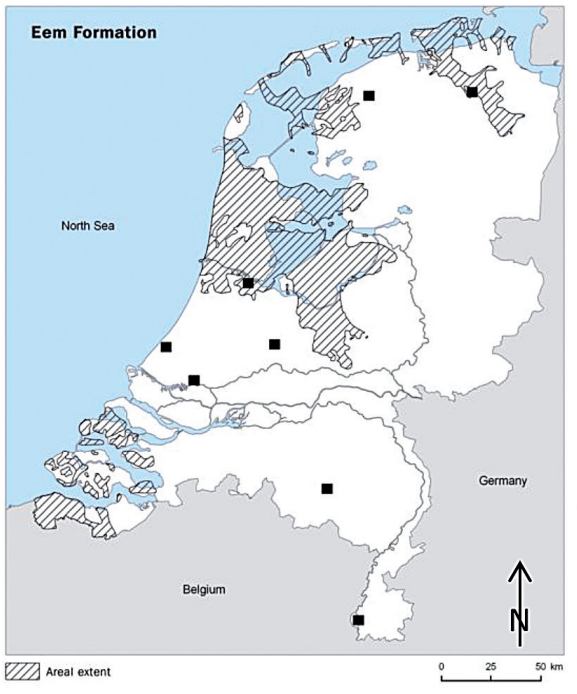

$b$.

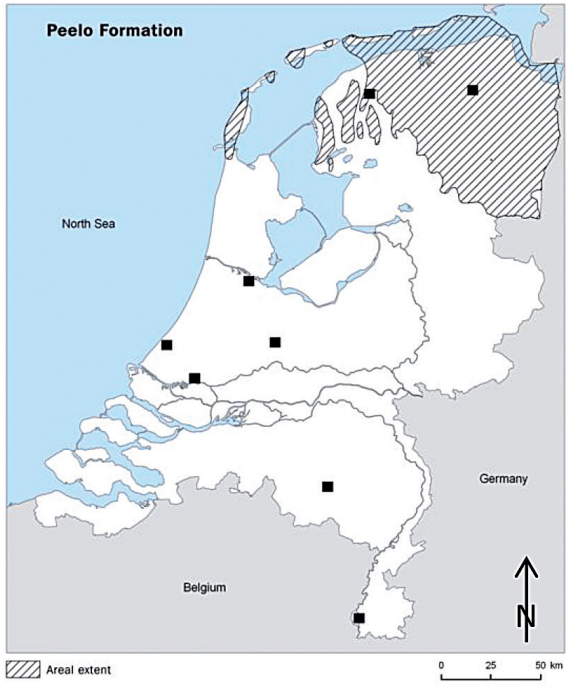

VID Areal extent

Fig. 5. Potential areal extent of: $a$. Holocene unit; b. Eem Formation; c. Peelo Formation. 


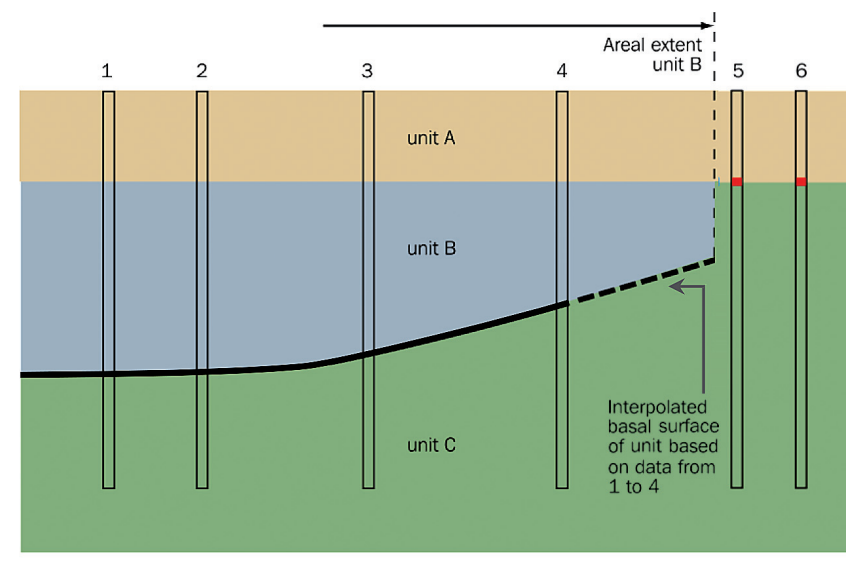

a.

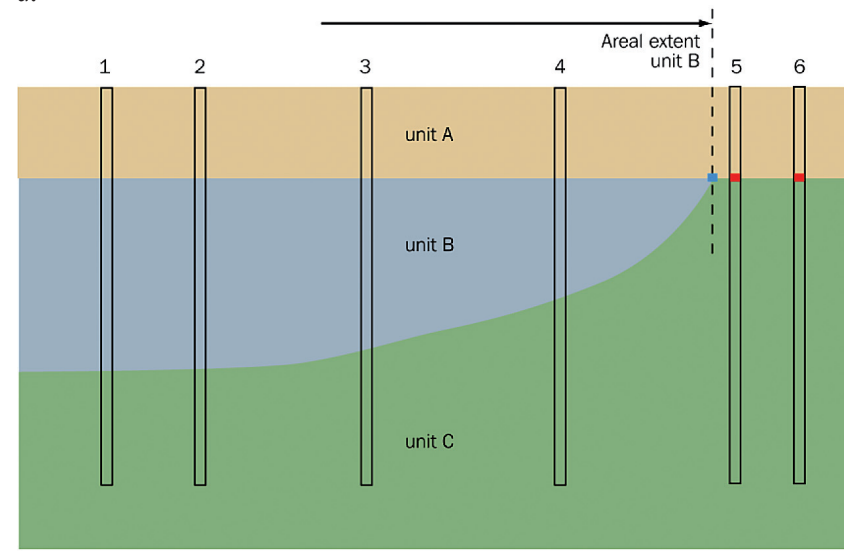

- unit B absent

- additional data to 'steer' pinching-out

$b$.

Fig. 6. The effect of introducing steering points. Figure 6 a shows interpolation results without steering points, in which case unit $B$ terminates abruptly. Figure $6 b$ shows the introduction of a steering point to guide the pinching out.

\section{Modelling workflow}

The modelling workflow consists of three steps: interpolation of the basal surfaces of each unit, stacking of the units to obtain a consistent 3D model and calculating the uncertainties of each unit. The workflow is automated in a flexible, modular way, which makes it possible to update the entire $3 \mathrm{D}$ model or only specific units.

\section{Interpolation}

The main reason for interpolating the basal rather than the top surface of a unit is that the basal surface is formed by geological

Fig. 7. a. Trend surface of the base of the Peelo Formation. The depth of the glacial tunnel valleys (which run predominantly north-south) is based upon a few boreholes and geological expert knowledge; $b$. Trend surface of the base of the Oosterhout Formation. This surface is calculated using the few available boreholes and general geological knowledge and is meant to give a general trend and not to fit the data exactly.

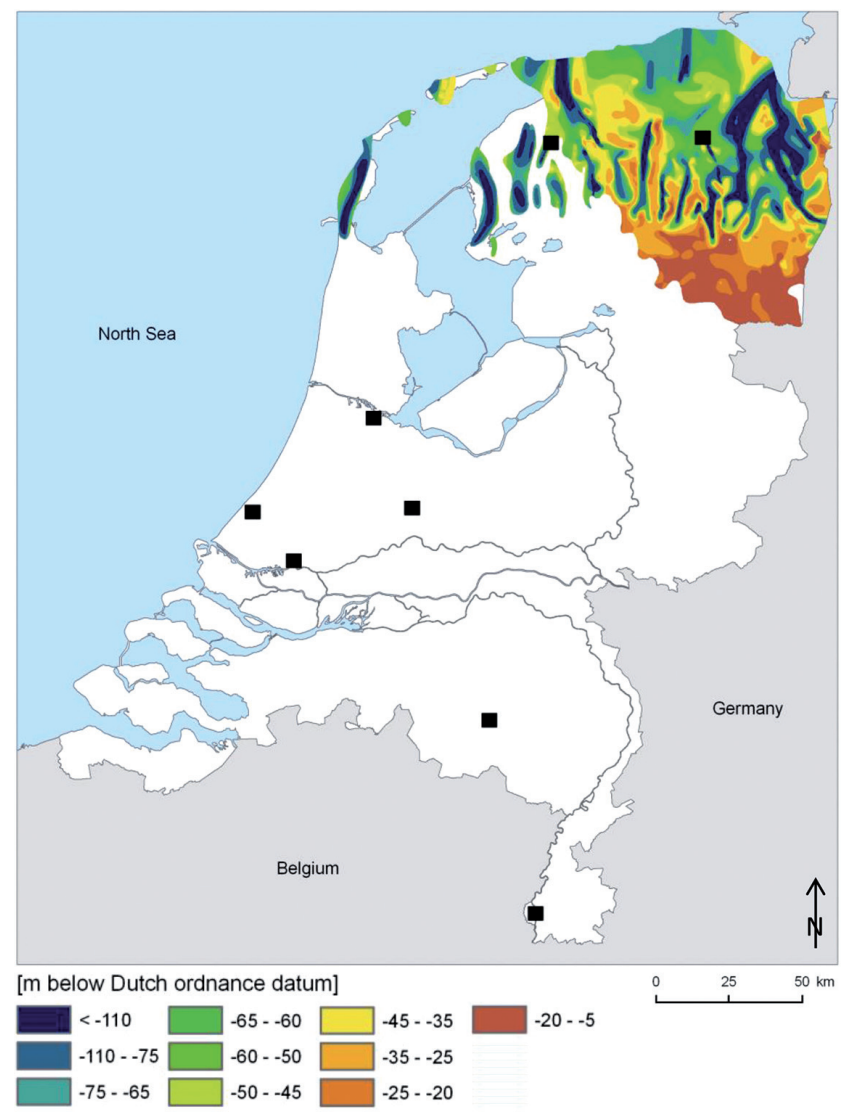

a.

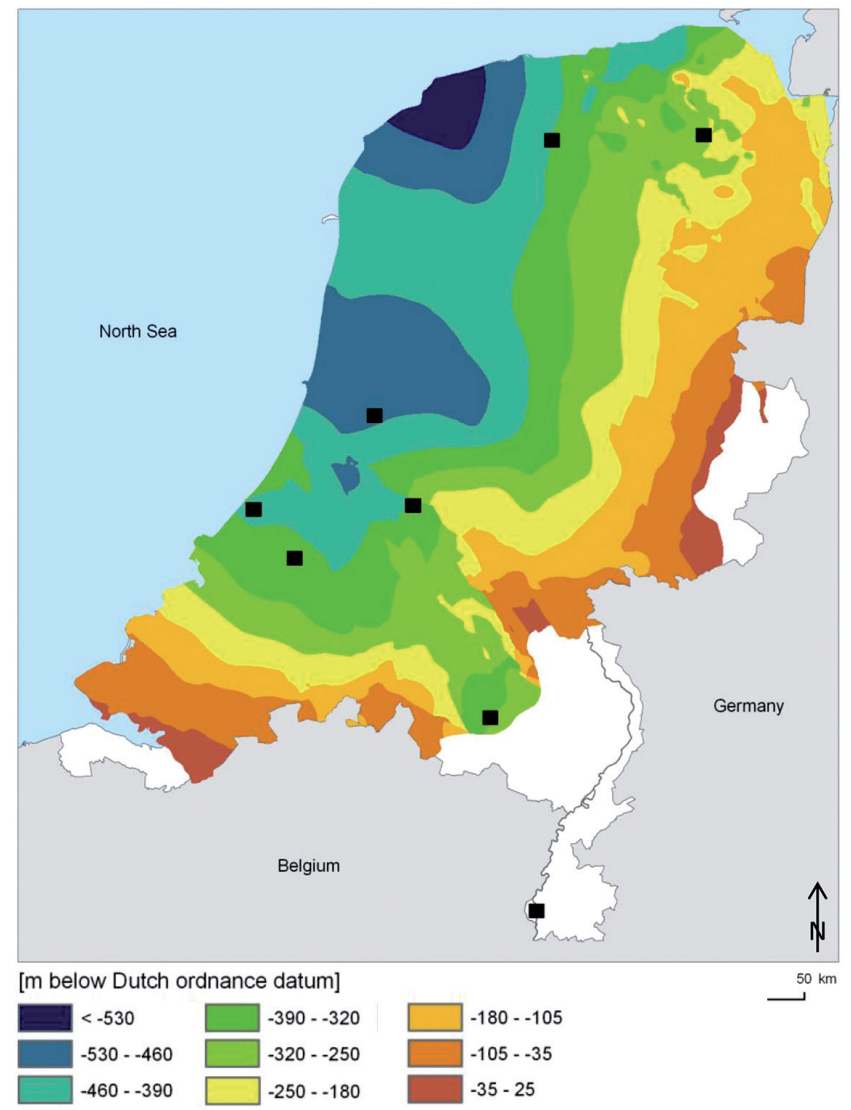

b. 
processes uniquely related to the unit. Interpolation of the top surface of a unit is less suitable because the top is also the result of later geological processes, unrelated to the deposition of the unit.

Ordinary block-kriging was used as the main interpolation technique (Isaaks \& Srivastava, 1989; Goovaerts, 1997). The interpolation procedure consists of a sequence of block-kriging interpolations carried out to obtain the best surface fitting the data (borehole data as well as all the other data mentioned). The interpolation procedure was adapted for each individual unit in order to address unit-specific geological characteristics and depositional history. This results in variograms and searchneighbourhoods (both key elements in the interpolation) that are unit specific.

Faults were taken into account in the interpolation because they act as divides across which data needs to be handled separately. Trend surfaces were incorporated by comparing the actual base of a unit at the borehole location with the trend surface. The difference (residual) was interpolated and subsequently added to the trend surface. In this way, the general form of the geological trend surface has been honoured, as well as the information from the boreholes. In areas where no trend surface was applied and data density was low, additional (geological) steering points were introduced to manipulate the surface in such a way that it conforms to the most plausible geological interpretation. The influence of these additional points is limited to their immediate surroundings, because the interpolation uses a local neighbourhood and the additional points are not used in areas where there are enough data to perform the interpolation.

\section{Creating the 3D model}

The next step in the workflow consisted of stacking each modelled basal surface in a stratigraphically consistent way in order to create the 3D framework model, and so define the top, base and thickness of each unit. Because the basal surfaces were modelled separately, stacking of the modelled surfaces caused some intersections between the layers. Fig 8a sketches a hypothetical situation after interpolation of the individual basal surfaces. In Fig. $8 \mathrm{~b}$ the result of a correct stacking of the units is displayed. In general there are three types of intersections. The first arises when (i) the upper unit intersects lower units. In geological terms this means that the upper unit has eroded underlying units. As a result of the stacking the upper unit clips the lower units. A second case of intersection exists when (ii) the upper unit has been deposited against the relief of the lower unit. In this case the lower unit clips the upper unit. The third type of intersection is formed when (iii) the upper and lower units intersect, yet geologically they are known to be conformable. This is regarded as an artefact of the interpolation procedure. In this case the difference in depth level of the units involved is averaged over the depth interval in which the intersection occurs, thereby undoing the intersection.

The procedure of creating the $3 \mathrm{D}$ model by stacking the layers is programmed in the workflow and is performed by gridto-grid operations available in GIS software ArcGIS (ESRI, 2010) and gridding software Isatis (Geovariances, 2011). The resulting 3D model consists of the base of all modelled units from which, as a result of the stacking, top and thickness have been derived. It is important to stress that a thorough geological understanding of the relationships between the units is necessary to make the right choice concerning the nature of the intersections.

\section{Estimating model uncertainties}

DGM consists of basal surfaces and, as a result of the stacking of the units, tops and thicknesses of the geological units that are modelled. These all have a - spatially varying - uncertainty that is (among others) related to uncertainties in: point $(\mathrm{x}, \mathrm{y})$ locations, reference level (NAP), lithostratigraphical classification $(\mathrm{z})$ and uncertainty resulting from the interpolation, which includes the uncertainties related to prior geological knowledge incorporated in the modelling procedure, like trend surfaces and steering points. We focus on the quantification of the uncertainties in the surfaces resulting from the interpolation, since the other uncertainties are hard to quantify.

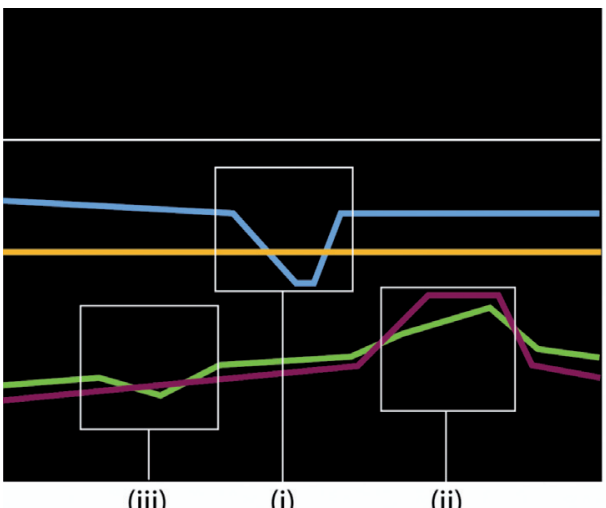

(iii)

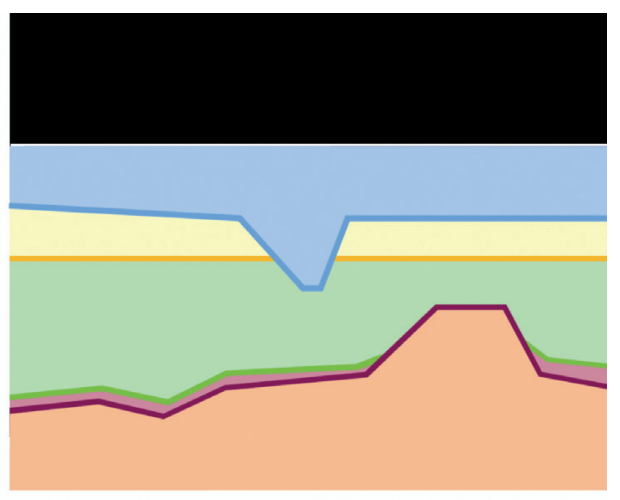

$b$.
Fig. 8. Stacking of DGM units, according to their stratigraphical position. Figure 8 a shows the individual basal surfaces. Figure $8 b$ shows the results of the stacking, based on the modelling decisions for dealing with the intersections; (i) denotes erosion, (ii) denotes deposition against existing relief, (iii) denotes conformity. 
The block-kriging method used comes with a kriging variance as a measure of interpolation uncertainty. It is hard to quantify the degree of uncertainty from the 'soft' information sources (trend surfaces, steering points) and their contribution to the total interpolation uncertainty. Added to this is the assumption that stationarity and multi Gaussian distribution, necessary for a correct interpretation of the kriging variance, is often violated by adding supplementary information. We therefore conclude that the kriging variance is not a reliable measure of uncertainty in our modelling procedure.

To overcome this problem we developed a procedure based solely on the 'hard' data from the lithostratigraphical interpretation of the boreholes and leaving out the a-priori knowledge altogether. We used cross-validation to estimate the difference between the true and the estimated value at each borehole location. The general principle of cross-validation is to leave out each data point - one at a time - and estimate the variable at that location using the remaining data points. By applying a moving-window, we were able to expand the uncertainties from the locations of the boreholes to the entire area of the unit and calculate the variance for each basal surface, also taking into account the borehole density (Gunnink et al., 2010). During the creation of the 3D model, by stacking the units, standard deviations for the top surface and thickness of each unit were deduced from the basal surface of the overlying unit.

\section{Results and applications}

DGM provides a nation-wide 3D geological model of the Netherlands on a regional scale. DGM contains the top and basal surfaces and thickness of the modelled units, together with their uncertainty. The model can be downloaded as a set of rasters. The model can be viewed on the internet via www.dinoloket.nl; this shows the geological units in a map viewer and it allows cross-sections to be made. Surfaces can be downloaded and viewed in 3D using a tailor-made visualisation programme. Point information can also be extracted from the model using a web service on www.dinoloket.nl. This can create a synthetic borehole at any location, specified by the user, with output in Excel consisting of a list of the units found at that location and the modelled depths of the units.

A brief overview of outputs from DGM is shown in Fig. 9. This shows surfaces, cross-sections and 'birds-eye' views of some geological units. Also, the spatial distribution of the standard deviation of the modelled base is presented for some units, including a cross-section showing the variation in the basal surface of the Kreftenheye Formation (Fig. 10 and 11). In addition to the visual presentation of the calculated layers, we have calculated the sediment volumes of all modelled geological units that were modelled across the country. The results are presented in Fig. 12.

It must be stated here that presenting 3D information in a static way using $2 \mathrm{D}$ 'snapshots' from the model is not the best way to convey the value of the model. A much better appreciation of the $3 \mathrm{D}$ model is obtained by using interactive 3D software, in which the sometimes complex relations between the geological units can be studied in detail.

The DGM project was initiated to meet the growing demands of usability and applicability of geological data and models. By creating DGM as a framework model, the Geological Survey made a step towards delivering geologic information for further use in applications that rely on subsurface information. Some applications are described below.

\section{REGIS-II}

DGM is used as the basis for the regional hydrogeological model, REGIS-II (Vernes \& Van Doorn, 2005), serving as the starting point for further subdivision of the modelled geological units into hydrogeological units, aquifers and aquitards, using the same basic workflow procedure as in DGM. Using the lithological information from the boreholes and additional hydrological data like groundwater heads and pumping tests, the hydrogeological units are characterised in terms of their hydraulic conductivity, transmissivity and hydraulic resistance. The hydrogeological units are constrained within the units of DGM, to ensure consistency between the geological and hydrogeological model. The REGIS model can be downloaded from www.dinoloket.nl. In Fig. 13, a cross-section is shown that displays both the results from DGM and that from REGIS, indicating the strong link between the two models.

\section{GeoTOP}

Furthermore, DGM provides the geological framework for modelling the internal structure and composition of geological units into facies, lithological properties and other parameters for applied research. This mapping programme, GeoTOP, uses a voxel approach in which the subsurface - up to $30 \mathrm{~m}$ depth - is subdivided into volumes of $100 \times 100 \times 0.5 \mathrm{~m}$. This allows modelling of detailed geological structures and facies distribution. DGM is used to define the main geological units and their bounding surfaces are refined by incorporating more data from the DIN0 database. See Stafleu et al. (2011) for more information regarding the GeoTOP modelling. Results and 3D viewing of GeoTOP can be found on www.dinoloket.nl.

\section{Aggregate resources}

DGM was used as one of the inputs to create the application 'Delfstoffen Online' (aggregate resources-online), in which the availability of raw building materials is modelled nationwide (Van der Meulen et al., 2005). DGM served as a framework, delivering the bounding surfaces within which the modelling of the lithology classes (clay, peat, fine sand, coarse sand, gravel) was executed. In this way, the modelling honours the geological constraints of DGM. The application can be found on www.dinoloket.nl. 


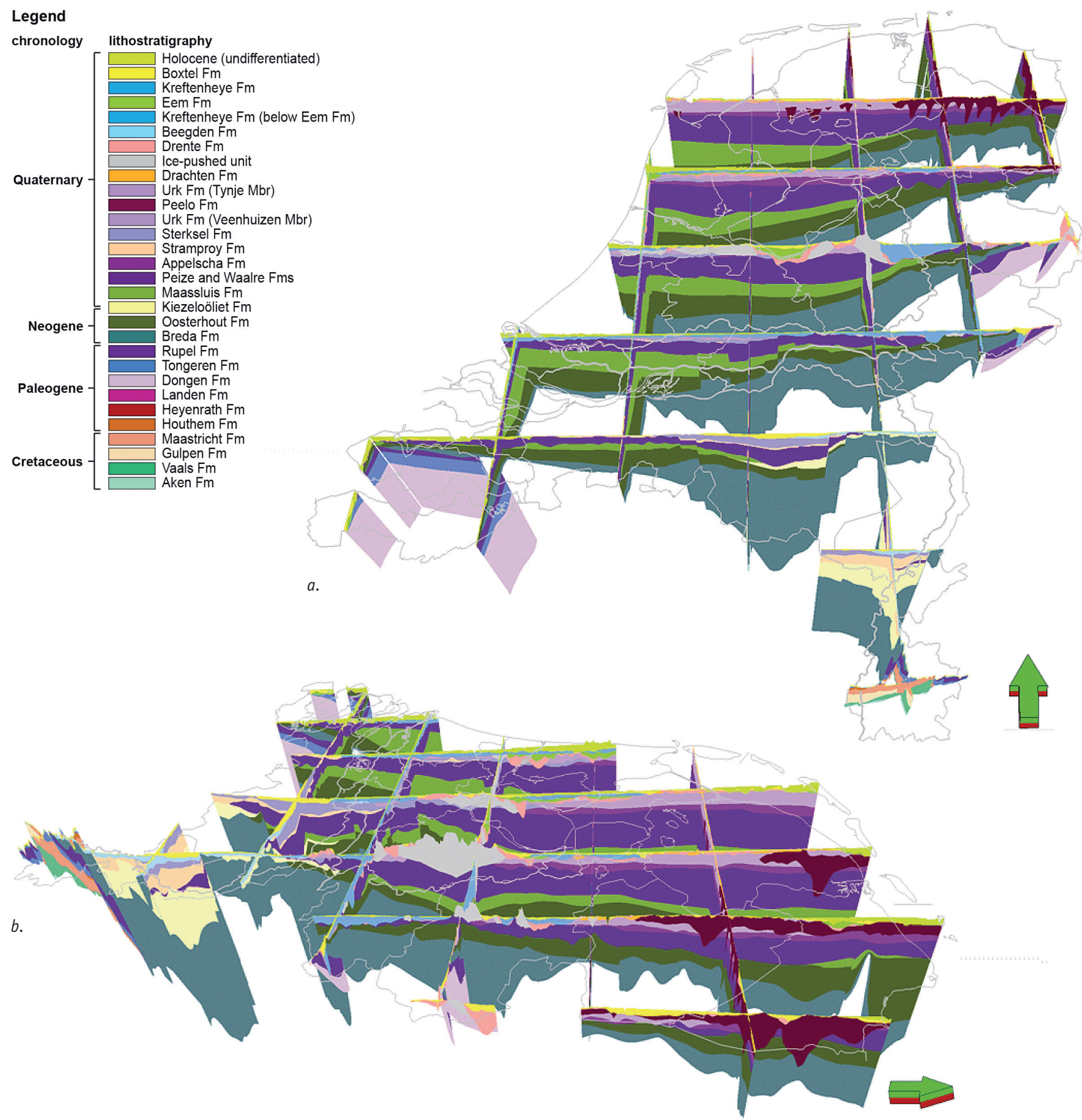

Fig. 9a, b. Cross-sections through DGM, $9 a$ looking north, $9 b$ looking west. The figures show the basin fill in the middle and western part of the Netherlands (Breda, Oosterhout and Maassluis Formations) and the shallower fringe of the basin in the east, to which the above-mentioned formations pinch-out. In the southern part of the country the Roer Valley Graben with its thick deposits of late Neogene and early Quaternary sediments is seen. In the southwest and easternmost part of the Netherlands, Neogene units (Rupel Formation and older) are close to the surface, while in the southernmost part the oldest sediments (up to Cretaceous) are shown.

\section{Subsidence}

Several studies were carried out to estimate the subsidence that might occur as a consequence of continuing the current land use and (artificial) groundwater regime, especially in polder areas (Bruggeman et al., 2011; Huisman et al., 2011; Vonhögen et al., 2010). DGM delivered the base of the Holocene unit. This unit is most prone to subsidence.

\section{Local detail}

Local studies often require additional data to be incorporated in DGM to map local structures. Besides boreholes, these data may include geotechnical (e.g. cone penetration tests) and geophysical (e.g. gamma-ray) measurements. Typically, these types of measurements not only provide additional information on subsurface properties but also show a higher vertical data 

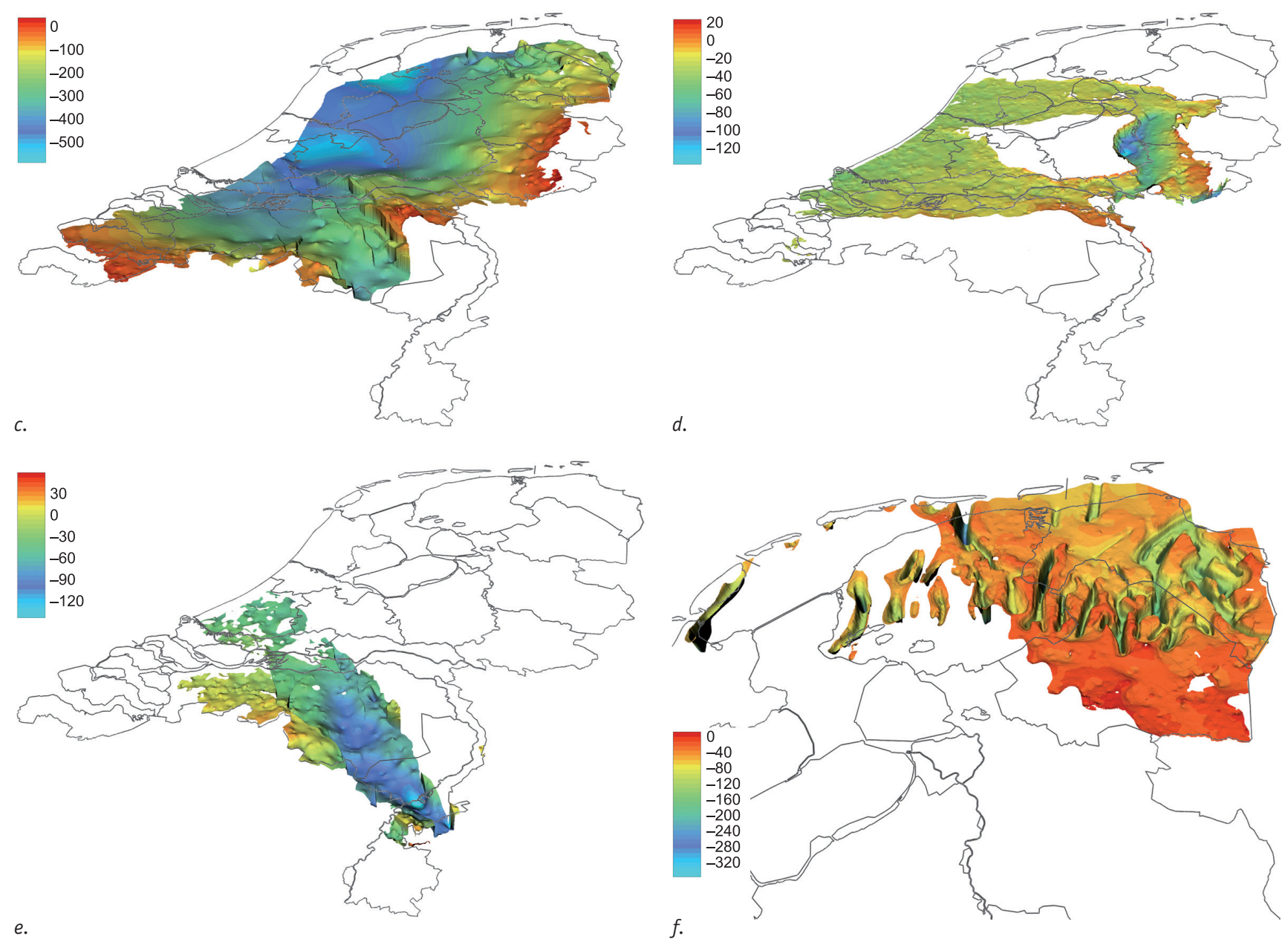

e.

$f$.
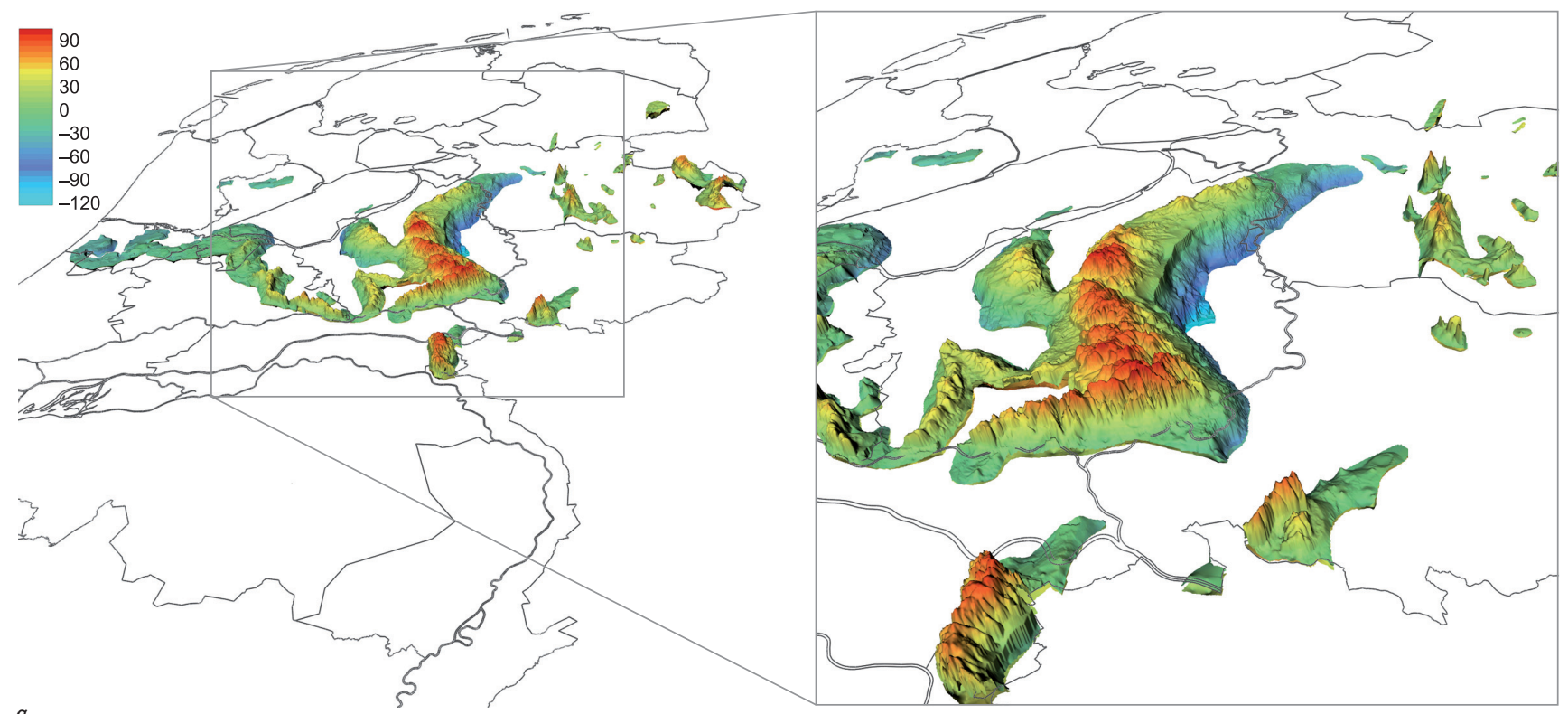

Fig. $9 c-g$. Figure $9 c$ displays the base of the Oosterhout Formation. The basal surface is ranging from $+30 \mathrm{~m}$ in the east and south to more than $-500 \mathrm{~m}$ in the northwest, indicating the subsidence of the North Sea basin. Figure $9 d$ shows the base of Late Pleistocene Rhine deposits of the Kreftenheye Formation, displaying the two major river courses and the deep glacial basin in the eastcentral part of the country ('IJssel valley') that acted as a sink. Figure ge shows the regionally confined distribution of the Stramproy Formation, which is mainly deposited in the Roer Valley Graben. Figure $9 f$ shows the base of the Peelo Formation, with deep erosional incisions, called buried valleys, that were formed under an ice-sheet. Figure $9 g$ displays the Ice-pushed Formation, for which the top and base are displayed together, thus showing its volume. 

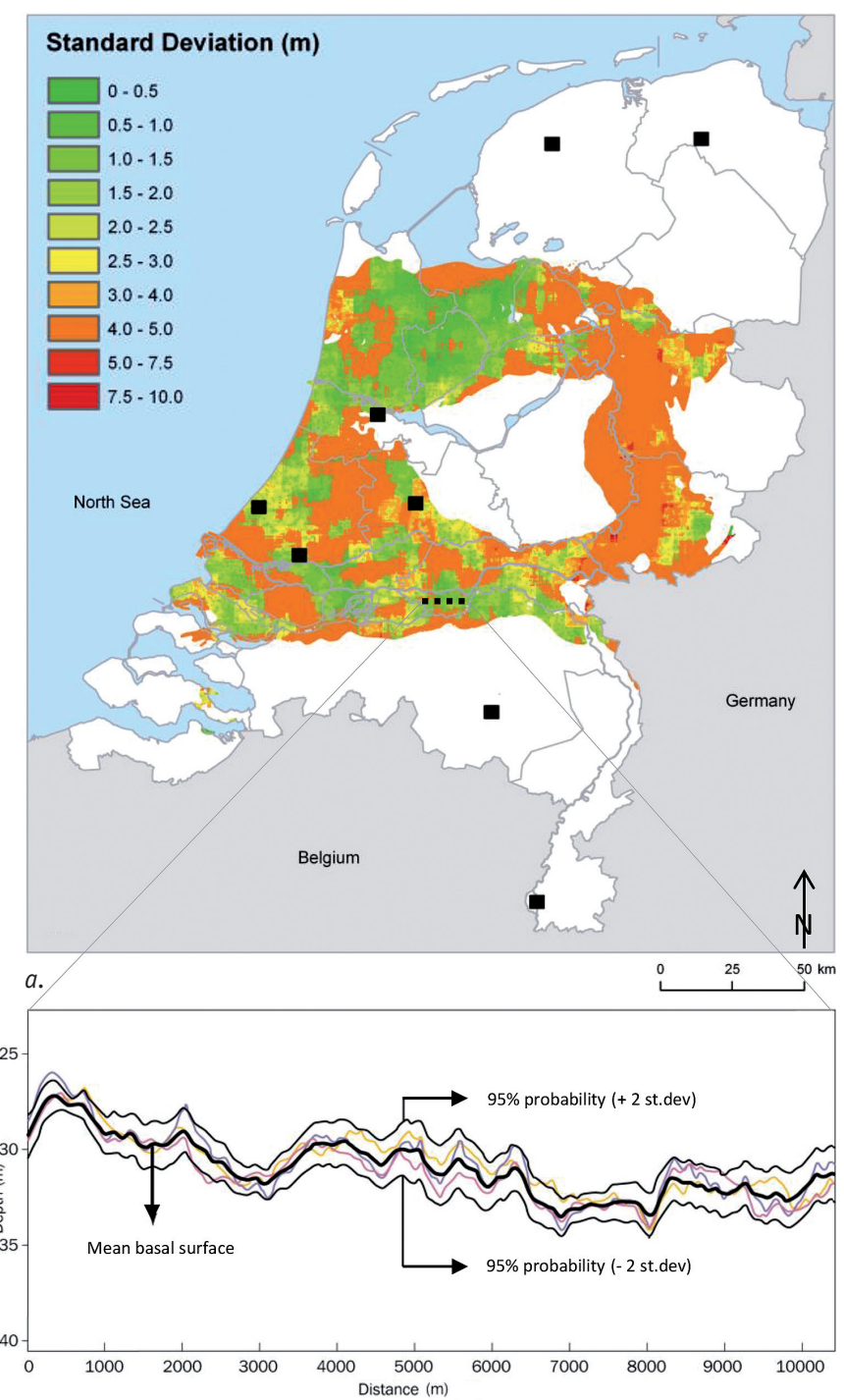

b.

Fig. 10. a. Standard deviation of the basal surface of the Kreftenheye Formation; b. Cross-section showing the basal surface of the Kreftenheye Formation and equal-probable realisations, calculated from the mean and standard deviation surfaces (coloured lines). Also the upper and lower boundary of the $95 \%$ probability interval are shown, indicating that there is a $95 \%$ probability that the basal surface is within these limits.

density compared to lithological core descriptions. DGM primarily serves as a guiding tool for the interpretation of the additional data: the surfaces of the units are used as references to steer the modelling of local structures, for example as trend surfaces or to aid the lithostratigraphical interpretation of local data.

The automated workflow of DGM makes it possible to update the 3D model whenever it is desirable, whether it involves only minor changes in the input data or major changes, for example conceptual modifications. DGM and the modelling principles behind it provide a consistent geological framework for interpreting and modelling of the subsurface. Besides the value of

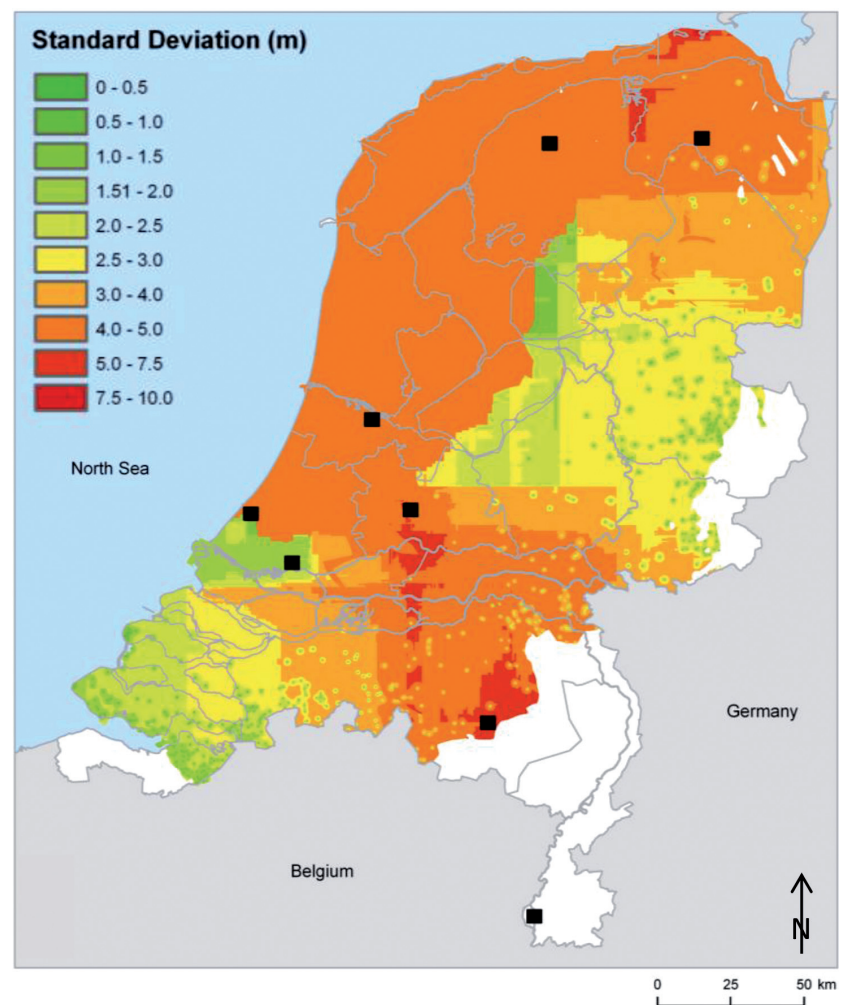

Fig. 11. Standard deviation of basal surface of the Oosterhout Formation. The uncertainty increases to the northwest, due to a poor coverage of boreholes that penetrate into this formation. The 'blocky' nature of the distribution of the standard deviation is due to the 'moving window' that is used.

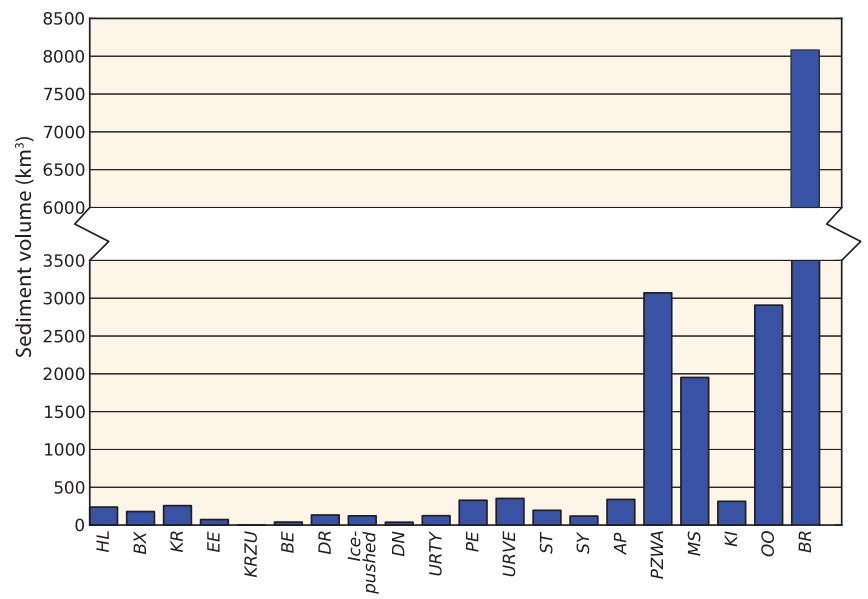

Fig. 12. Sediment volume $\left(\mathrm{km}^{3}\right)$ per unit. Only the Quaternary and Neogene units that are modelled over the entire country are shown. For abbreviations see Table 1.

the geological insights it provides, the main merits of DGM are in providing a systematic framework for assessing earth resources and geohazard potential. 


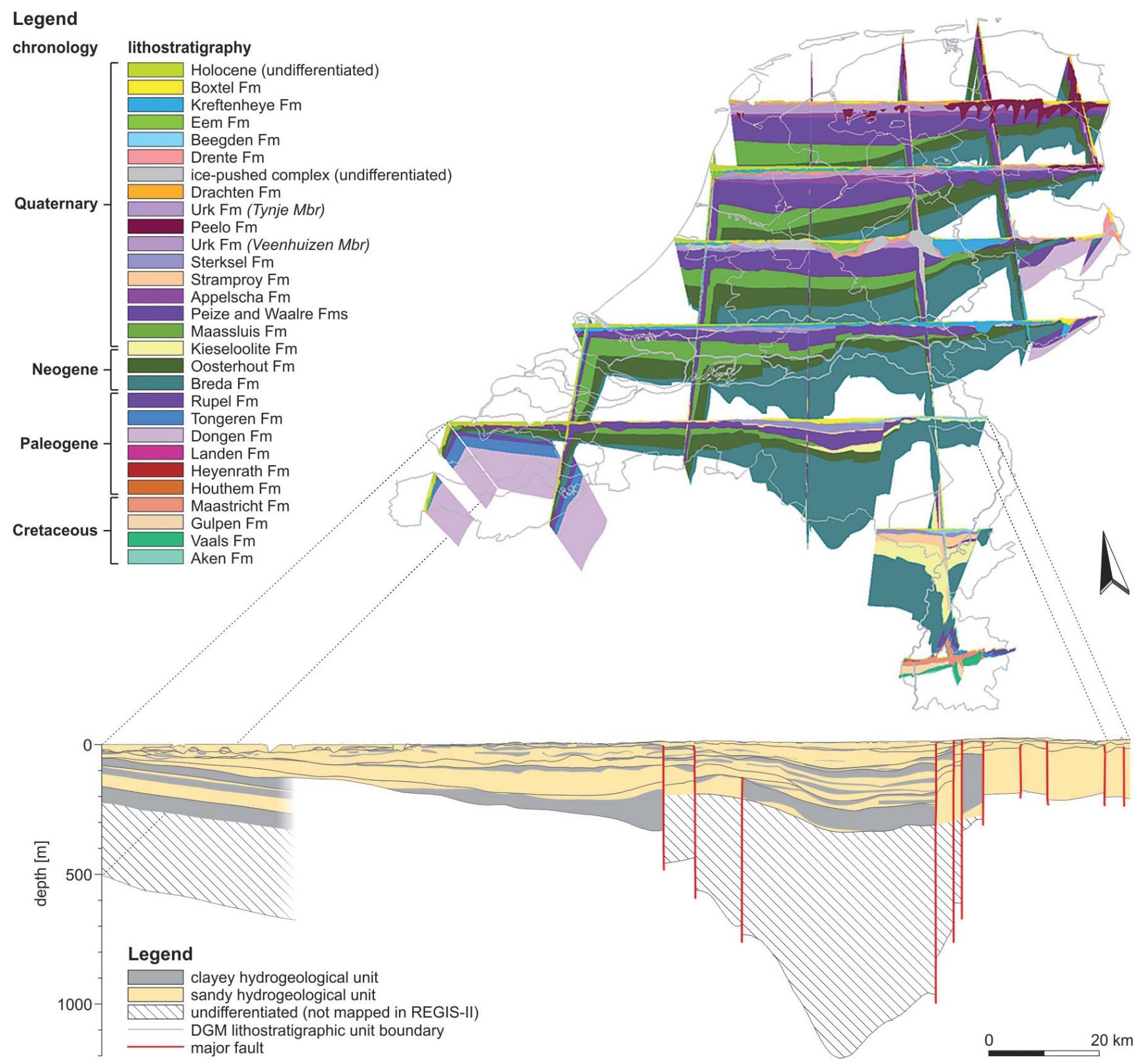

Fig. 13. Fence diagram through DGM with the lower panel showing the REGIS-II distribution of aquifers (lighter colours) and aquitards (darker colours). Note that the hydrogeological units are constrained by DGM unites. The REGIS model does not cover the entire depth interval of DGM in some areas due to limited borehole information.

\section{Acknowledgements}

Jenny Hettelaar and Han Bruinenberg are gratefully acknowledged for assistance in creating figures. Wim Westerhoff and Aleid Bosch are thanked for their valuable comments, and colleagues from the Geomodelling department of the Geological Survey are acknowledged for their fruitful discussions and cooperation. The comments of Diarmad Campbell (BGS) and an anonymous reviewer helped to improve the manuscript considerably.

\section{References}

Berg, R.C., Mathers, S.J., Keefer, D.A. \& Kessler, H., 2011. A synopsis of current Three-dimensional geological mapping and modeling in Geological Survey Organizations.Illinois State Geological Survey open file report, Circular 578.

Bruggeman, W., Haasnoot, M., Hommes, S., Te Linde, A., Van der Brugge, R., Rijken, B., Dammers, E. \& Van der Born, G.J., 2011. Deltascenario's: Verkenning van mogelijke fysieke en sociaaleconomische ontwikkelingen in de $21^{\text {ste }}$ eeuw op basis van KNMI'06 en WLO-scenario's voor gebruik in het Deltaprogramma 2011-2012. Planbureau voor de Leefomgeving / Deltares, Rapport 1205747-000, $125 \mathrm{pp}$. 
Ebbing, J.H.J., Weerts, H.J.T. \& Westerhoff, W.E., 2003. Towards an integrated land-sea stratigraphy of the Netherlands. Quaternary Science Reviews 22: 1597-1587.

ESRI, 2010. ArcGIS Desktop 10. ESRI Inc. (Redlands, USA).

Geovariances, 2011. Isatis technical reference 201: 198 pp. Available at: www.geovariances.com.

Goovaerts, P., 1997. Geostatistics for Natural Resources Evaluation. Oxford University Press (New York), 483 pp.

Gunnink, J.L., Maljers D. \& Hummelman, J.H., 2010. Quantifying uncertainty of geological 3D layer models, constructed with a-priori geological expertise. IAMG 2010 (Budapest).

Huisman, D.J., Bouwmeester, J., De Lange, G., Van der Linden, Th., Mauro, G., Ngan-Tillard, D., Groenendijk, M., De Ridder, T., Van Rooijen, C., Roorda, I. \& Stoevelaar, $R_{\text {., }}$ 2011. De invloed van bouwwerkzaamheden op archeologische vindplaatsen. Rijksdienst voor het Cultureel Erfgoed (Amersfoort), 53 pp.

Isaaks, E.H \& Srivastava, R.M., 1989. An introduction to Applied Geostatistics. 0xford University Press (New York), 561 pp.

NITG-TNO, 1997-2000. Toelichtingen bij de Geologische kaart van Nederland 1:50.000. Nederlands Instituut voor Toegepaste Geowetenschappen TNO (Utrecht).

NITG-TNO, 2004. Geological Atlas of the subsurface of the Netherlands - onshore, $101 \mathrm{pp}$.

RGD, 1953-1997. Toelichtingen bij de Geologische kaart van Nederland 1:50.000. Rijks Geologische Dienst (Haarlem).

Stafleu, J., Maljers, D., Gunnink, J.L., Menkovic, A. \& Busschers, F.S., 2011. 3D modelling of the shallow subsurface of Zeeland, the Netherlands. Netherlands Journal of Geosciences 90: 293-310.

Staring, W.C.H., 1856. De bodem van Nederland. De zamenstelling en het ontstaan der gronden in Nederland ten behoeve van het algemeen beschreven. Deel 1. Kruseman (Haarlem), $441 \mathrm{pp}$.

Staring, W.C.H., 1860. De bodem van Nederland. De zamenstelling en het ontstaan der gronden in Nederland ten behoeve van het algemeen beschreven. Deel 2. Kruseman (Haarlem), 480 pp.

Tesch, $\boldsymbol{P}_{\text {., }}$ 1942a. Hoofdstuk II. Overzicht van de geschiedenis der geologische kaart in Nederland. In: Tesch, P. (ed.): Toelichtingen bij de geologische kaart van Nederland. De Geologische kaart van Nederland en hare beteekenis voor verschillende doeleinden. Mededelingen van de Geologische Stichting Serie D-1: 8-12.

Tesch, P., 1942b. Hoofdstuk III. Grondslagen van de Kaart. Indeeling en gebruiksaanwijzing. In: Tesch. P. (ed.): Toelichtingen bij de geologische kaart van Nederland. De Geologische kaart van Nederland en hare beteekenis voor verschillende doeleinden. Mededelingen van de Geologische Stichting Serie D-1: 13-31.

Van der Meulen, M.J., Van Gessel, S.F. \& Veldkamp, J.G., 2005. Aggregate resources in the Netherlands. Netherlands Journal of Geosciences 84: 379-387.

Vernes, R.W. \& Van Doorn, Th.H.M., 2005. Van Gidslaag naar Hydrogeologische eenheid- Toelichting op de totstandkoming van REGIS II. TNO-rapport NITG 05-038-B, 105 pp.

Vonhögen, L.M., Doornenbal, P.J., De Lange, G., Fokker, P.A. \& Gunnink, J.L., 2012. Subsidence in the Holocene delta of the Netherlands. Proceedings of EISOLS 2010: Land subsidence, Associated Hazards and the role of Natural Resources Development.
Weerts, H.J.T., Westerhoff, W.E., Cleveringa, P., Bierkens, M.F.P., Veldkamp, J.G. \& Rijsdijk, K.F., 2004. Quaternary geological mapping of the lowlands of the Netherlands, a $21^{\text {st }}$ century perspective. Quaternary International 133-134: 159-178.

Westerhoff, W.E., 2009. Stratigraphy and sedimentary evolution. The lower Rhine-Meuse system during the Late Pliocene and Early Pleistocene (southern North Sea Basin). PhD thesis, Vrije Universiteit Amsterdam, 168 pp.

Westerhoff, W.E., Wong, T.E. \& Geluk, M.C., 2003. De opbouw van de ondergrond. In: De Mulder, E.F.J., Geluk, M.C., Ritsema, I., Westerhoff, W.E. \& Wong, T.E. (eds): De ondergrond van Nederland. Nederlands Instituut voor Toegepaste Geowetenschappen TN0 (Urecht). Geologie van Nederland 7: 247-352.

Zagwijn, W.H. \& Van Staalduinen, C.J. (eds), 1975. Toelichting bij geologische overzichtskaarten van Nederland. Rijks Geologische Dienst (Haarlem): 11-56. 